\title{
PLANIMETRÍA DE TRES CATEDRALES ESPAÑOLAS: SEGOVIA, BURGOS Y PALENCIA
}

\author{
(SURVEYS OF THREE SPANISH CATHEDRALS: SEGOVIA, BURGOS, PALENCIA)
}

\section{RESUMEN}

El levantamiento de planos por métodos actuales, instrumentos niveladores y metrología directa de campo aportan al conocimiento, desarrollo y conservación de los monumentos o edificaciones antiguas, importantes bases de datos no sólo para el conocimiento documental de la Historia, sino también y muy en especial, para el correcto cálculo del comportamiento estructural y constructivo a efectos de su conservación o control. Se publican y aportan, por primera vez con estos objetivos, los últimos

levantamientos de tres catedrales españolas: Segovia, Burgos y Palencia.

La referencia a la documentación antigua es un elemento imprescindible para ese mismo análisis que toda restauración requiere. (Documentación del arquitecto José Sancho Roda).

\section{SUMMARY}

Surveying by modern methods, levelling instruments, and direct metrology of the area help to further knowledge, development and conservation of monuments and ancient buildings, by creating important sources of information not only relating to the documental history of the building but also specifically in facilitating correct calculations of the building's structural make-up and construction for the purpose of conservation and control. These objectives are to be brought forward for the first time in the publication of the most recent surveys of three Spanish cathedrals: Segovia, Burgos and Palencia.

Reference to foregoing documentation is indispensable for this analysis which is necessary for restauration.

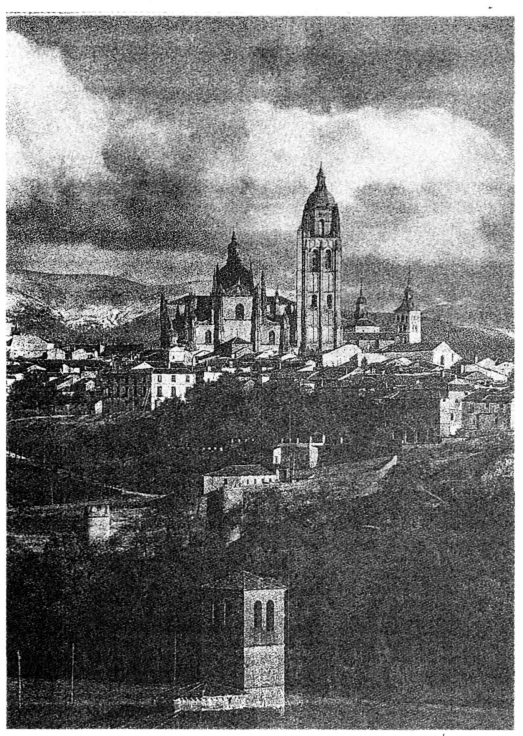

Catedral de Segovia

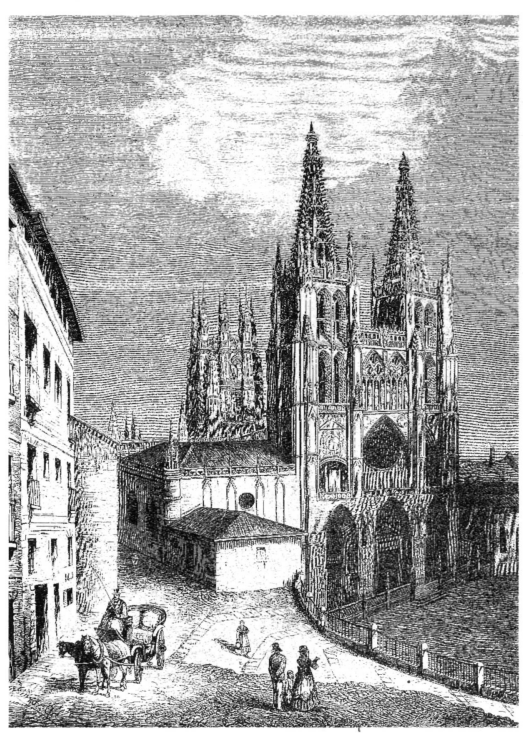

Catedral de Burgos

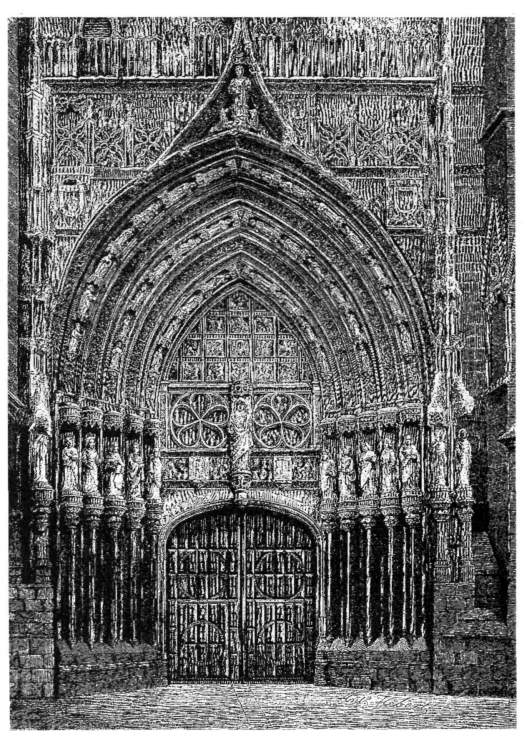

Catedral de Palencia

La documentación de grabados, fotos y planimetrias antiguas ha sido cedida por el arquitecto José Sancho Roda. 